\title{
Hypoglycemic effects of the aqueous extract of African Mistletoe, Tapinanthus sesselifolius (P. Beauv) van Tiegh (Loranthaceae)
}

\author{
Florence David TARFA ${ }^{1,3^{*}}$, Samson AMOS ${ }^{2}$, Victor J. TEMPLE ${ }^{3}$, \\ Nelson A. OCHEKPE ${ }^{4}$ and Karniyus Shingu GAMANIEL ${ }^{2}$ \\ ${ }^{I}$ Department of Medicinal Chemistry and Quality Control, National Institute for Pharmaceutical Research and \\ Development (NIPRD), Idu Industrial Area, P.M.B. 21,Garki, Abuja, Nigeria. \\ ${ }^{2}$ Department of Pharmacology and Toxicology, NIPRD, Abuja, Nigeria. \\ ${ }^{3}$ Division of Basic Medical Sciences, School of Medical Sciences, University of Papua New Guinea. \\ ${ }^{4}$ Department of Pharmaceutical Chemistry, UNIJOS, Jos, Nigeria. \\ *Corresponding author, E-mail: tarfaf@yahoo.co.uk ; Tel: +2348059486323
}

\begin{abstract}
The hypoglycemic effect of the aqueous extract of African mistletoe, Tapinanthus sesselifolius, was investigated in-vivo and in-vitro. Studies were carried out on normoglycemic and alloxan-induced hyperglycemic rabbits, and glucose uptake studies were done using the isolated intestine of normal rabbits. The safety studies (acute toxicity test) were carried out in mice. The results revealed that the aqueous extract of Tapinanthus sesselifolius exhibited transient reduction of blood glucose in normoglycemic rabbits and significantly lowered blood glucose level in hyperglycemic rabbits. The extract significantly decreased the level of glucose in serosal fluid dose dependently. The intraperitoneal (i.p.) $\mathrm{LD}_{50}$ of Tapinanthus sesselifolius was found to be $2000-2650 \mathrm{mg} / \mathrm{kg}$ within $95 \%$ confidence limits. The preliminary phytochemical screening showed positive test for biologically active substances such as saponins, tannins, flavonoids, terpenoids and glycosides. The data showed that Tapinanthus sesselifolius contain biologically active substances that may be useful in treatment of diabetes and thus gave a scientific basis for its use in herbal traditional medicine as an antidiabetic agent.
\end{abstract}

() 2012 International Formulae Group. All rights reserved.

Keywords: Phytomedicine, alloxan-induced hyperglycemia, glucose uptake.

\section{INTRODUCTION}

Diabetes mellitus is a metabolic disease characterized by chronic hyperglycemia resulting from defects in insulin secretion and / or insulin action, due to impaired function in carbohydrate, lipid and protein metabolism (Alarcor-Aguilar et al.,
2000). The disease affected about 171 million people worldwide in 2000 and the number is projected to increase to at least 366 million by 2030 (Wild et al., 2004).

The use of medicinal herbs in the treatment of various ailments including diabetes is common in developing countries 
especially in Africa (Afolayan and Sunmonu, 2010). Interestingly, the World health Organisation has encouraged the use of phytomedicine where access to conventional treatment of diabetes is not adequate (WHO, 1980). The plant family Loranthaceae has been known as a therapeutic herb (Fernandeze et al., 1998). African mistletoe, Tapinanthus sesselifolius (P. Beauv) Van Tiegh (Loranthaceae) is a semi parasitic plant widely distributed throughout Northern and Southern Nigeria and is found growing on a variety of evergreen deciduous trees. Unlike true parasites, mistletoe takes only water and mineral from its host and grows all year round along branches of its host (Hutchinson and Dalziel, 1972). Its green leaves enable it to photosynthesize carbohydrate (Griggs, 1991). In Nigeria and some parts of Africa, aqueous extract (infusion) of the dried leaves are used traditionally as a remedy for diabetes, hypertension and other metabolic disorders (Obatomi et al., 1994; Ilesanmi and Olawoyi, 2010). Our previous report shows that aqueous extract of Tapinanthus sesselifolius parasitic on Psidium guajava has activity on gastrointestinal muscle activity (Tarfa et al., 2002). The present study was undertaken to evaluate the scientific basis for the use of the plant as an antidiabetic agent by evaluating the hypoglycemic effects of the aqueous extracts of Tapinanthus sesselifolius parasitic on Psidium guajava in rodents. The safety of the extract $\left(\mathrm{LD}_{50}\right)$ and phytochemical constituents were also tested.

\section{MATERIALS AND METHODS \\ Plant material}

The leaves of $T$. sesselifolius were harvested from the host, Psidium guajava in October - November 2003 in Jos, Plateau State of Nigeria. The plant material was identified and authenticated by Prof. Z. O. Gbile (Consultant Taxonomist, UNDP). Voucher specimen (No. FHI 105336) was deposited at Forestry Research Institute, Ibadan.

\section{Preparation of extract}

The fresh leaves of $T$. sesselifolius were air-dried for 7 days and crushed into powder using mortar and pestle. Thirty two grams of powdered leaves were infused in a litre of water. The mixture was filtered and freeze-dried using Lyovac GT2 (Germany). The yield was found to be $13 \mathrm{~g}(41 . \% \mathrm{w} / \mathrm{w})$.

\section{Preliminary phytochemical screening of extract \\ The extracts was subjected to} qualitative chemical investigation for the identification of the different phytoconstituents like sterols, glycosides, saponins, carbohydrates, alkaloids, flavonoids, tannins, steroids and terpenoids using standard procedures (Harborne, 1998; Evans, 2002).

\section{Animals}

Swiss albino mice $(20-30 \mathrm{~g})$ were obtained from the Animal Facility Centre (AFC), Department of Pharmacology \& Toxicology, NIPRD, Abuja and 75\% crossbreed New Zealand rabbits, weight range 1.5 $-2.0 \mathrm{~kg}$, were brought from the Veterinary Research Institute, Vom, Jos. The animals were maintained on standard feed pellets and rabbit mesh and water ad libitum and were used in accordance to NIH Guide for the Care and Use of Laboratory Animals; NIH Publication (No. 83-23), The National Academic Press, Washington, DC (1985), and NIPRD's SOPs for animal usage.

\section{Acute toxicity studies}

The safety of the extract was assessed by determining the acute toxicity $\left(\mathrm{LD}_{50}\right)$ level using Lorke's (1983) method. The test was carried out in five groups, each consisting of five (5) mice. Groups I - IV were administered with varying doses of extract at 10, 100, 1000 and $2000 \mathrm{mg} / \mathrm{kg}$ p.o., while 
group $\mathrm{V}$ served as control and were administered normal saline at $10 \mathrm{ml} / \mathrm{kg}$. Signs and symptoms of toxicity were observed over a period of $24 \mathrm{~h}$. Death within this period was recorded and the $\mathrm{LD}_{50}$ was calculated from second stage of dosing as the square root of the lowest lethal dose and the highest non lethal dose (Vongtau et al., 2004).

\section{Biological assay}

Effect of Tapinanthus sesselifolius on normoglycemic rabbits

Twenty (20) rabbits of both sexes were randomly separated into four groups containing five (5) rabbits each. The animals were fasted for $18 \mathrm{~h}$ prior to testing and allowed water ad libitum. Animals in groups 1,2 and 3 received the extract at doses of 100 , 200 and $400 \mathrm{mg} / \mathrm{kg}$, p.o. respectively. Group 4 served as control and was given normal saline at $0.2 \mathrm{ml} / \mathrm{kg}$ p.o. Blood was withdrawn from ear vein after $2 \mathrm{~h}$ of drug administration. Blood glucose was monitored using glucose oxidase method of Trinder (1969) 2 hourly for a period of $8 \mathrm{~h}$.

Effect of Tapinathus sesselifolius on alloxan-induced hyperglycemia

Rabbits were fasted overnight and fasting glucose level determined. Alloxan monohydrate (Sigma) was freshly prepared as $10 \%$ solution in distilled water and was injected intravenously (i.v.) at a dose of 180 $\mathrm{mg} / \mathrm{kg}$. The rabbits were left for 14 days for blood glucose to stabilize and treatment commenced after the hyperglycemic condition was confirmed. The rabbits were randomly grouped into four (4) groups of five (5) rabbits each. Animals in groups 1, 2 and 3 received the extract at doses of 100, 200 and 400 $\mathrm{mg} / \mathrm{kg}$, p.o. respectively, while group 4 served as control and received $400 \mathrm{mg} / \mathrm{kg}$, p.o chlorpropamide. Blood glucose was determined using glucose oxidase method of Trinder (1969) at every $2 \mathrm{~h}$ for the first $8 \mathrm{~h}$, thereafter $24 \mathrm{~h}$ daily for seven days.
Absorption of glucose across intestinal wall of rabbit

Preparation of rabbit intestinal wall for glucose absorption

Rabbits were sacrificed and abdomen split open. The distal segment of the intestine about $(8-10 \mathrm{~cm})$ was cut, flushed of its contents, washed in Krebs Ringer's solution (mM); $\mathrm{NaCl} 118.8, \mathrm{KCl} 4.7, \mathrm{MgSO}_{4} 1.18$, $\mathrm{KH}_{2} \mathrm{PO}_{4} \quad 1.18, \mathrm{NaHCO}_{3} \quad 25, \mathrm{CaCl}_{2} \quad 1.25$, glucose 11(g); kept at $37{ }^{\circ} \mathrm{C}$ in a thermostatically heated water bath. The intestines were inverted. Eversion allows for the mucosal surface of the intestine to assume an external position, while serosal surface assumes an internal position. The inverted tissue was then introduced into an organ bath maintained at $37{ }^{\circ} \mathrm{C}$ tied at one end. In the control studies, the serosal fluid consisted of Kreb Ringer's solution only and was introduced into the internal segment of the inverted tissue, while mucosal fluid side consist of glucose $(5 \mathrm{mg} / \mathrm{kg})$. In the test group, the serosal fluid consisted of Kreb Ringer's solution, and the mucosal fluid consist of glucose and varying concentration of the extracts at $25 \mathrm{mg} / \mathrm{ml}, 50 \mathrm{mg} / \mathrm{ml}$ and 100 $\mathrm{mg} / \mathrm{ml}$. Sampling of the serosal fluid then started at zero time as it was being introduced into the serosal side in aliquots of $0.2 \mathrm{ml}$, then at $30 \mathrm{~min}$ interval for $120 \mathrm{~min}$. Glucose was determined for all the samples collected based on the glucose oxidase method (Okachi et al., 1997).

\section{Statistical analysis}

The results of the experiment were expressed as mean \pm SEM. Analysis of variance one way ANOVA followed by Newman Keuls was performed and sequential differences among means were calculated at a level of $\mathrm{P}<0.05 . u$ sing GraphPad Prism Version 5.2. for Windows, GraphPad software, San Diego California USA, www.graphpad.com. 


\section{RESULTS}

The $\mathrm{LD}_{50}$ was established to be 2000 $\mathrm{mg} / \mathrm{kg}$, i.p. Toxic signs include restlessness and sedation among groups that received high doses. Phytochemical screening shows the presence of flavonoids, terpenes, balsam, saponins and hydrolysable tannins in the aqueous extract.

Effect of Tapinanthus sesselifolius on normoglycemic rabbits

Tapinanthus sesselifolius at doses of 100,200 and $400 \mathrm{mg} / \mathrm{kg}$ caused a gradual decrease in blood glucose level. The effect peaked after $4 \mathrm{~h}$ with a mean reduction of blood glucose level of $13 \pm 1.2 \mathrm{mg} / \mathrm{dl}$ and then returned to normal levels (Figure 1). The decrease in blood glucose was not significant $(p>0.05)$ at $4 \mathrm{~h}$. This effect was different from that of chlorpropamide.
Effect of the extract on alloxan-induced hyperglycemia

The extract, 100, 200 and $400 \mathrm{mg} / \mathrm{kg}$ p.o. caused a mean fall in blood glucose level $(42.3 \pm 3.5,35.3 \pm 2.0$ and $45.0 \pm 3.0 \mathrm{mg} / \mathrm{dl})$ of animals treated with alloxan respectively. Similarly, chlorpropamide $400 \mathrm{mg} / \mathrm{kg}$ p.o. caused a mean reduction of $54.90 \pm 2.5 \mathrm{mg} / \mathrm{ml}$ (Figure 2). The decrease in blood glucose was significant $(\mathrm{p}<0.05)$ at the $7^{\text {th }}$ day of the experiments.

Effect of extract on glucose absorption across intestinal wall

The extract at 25, 50 and $100 \mathrm{mg} / \mathrm{ml}$ caused a concentration dependent decrease in glucose absorption across the intestinal lumen. This decrease was also time dependent (Table 1).

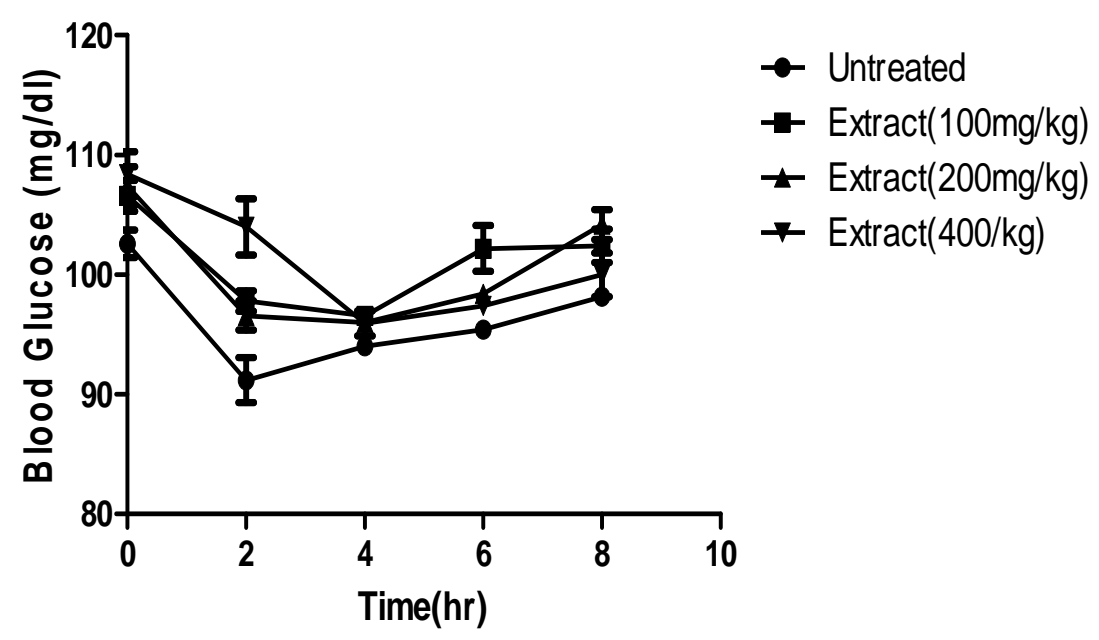

Figure 1: Effect of aqueous extract of Tapinathus sesselifolius on blood glucose levels in normoglycemic rabbits. 


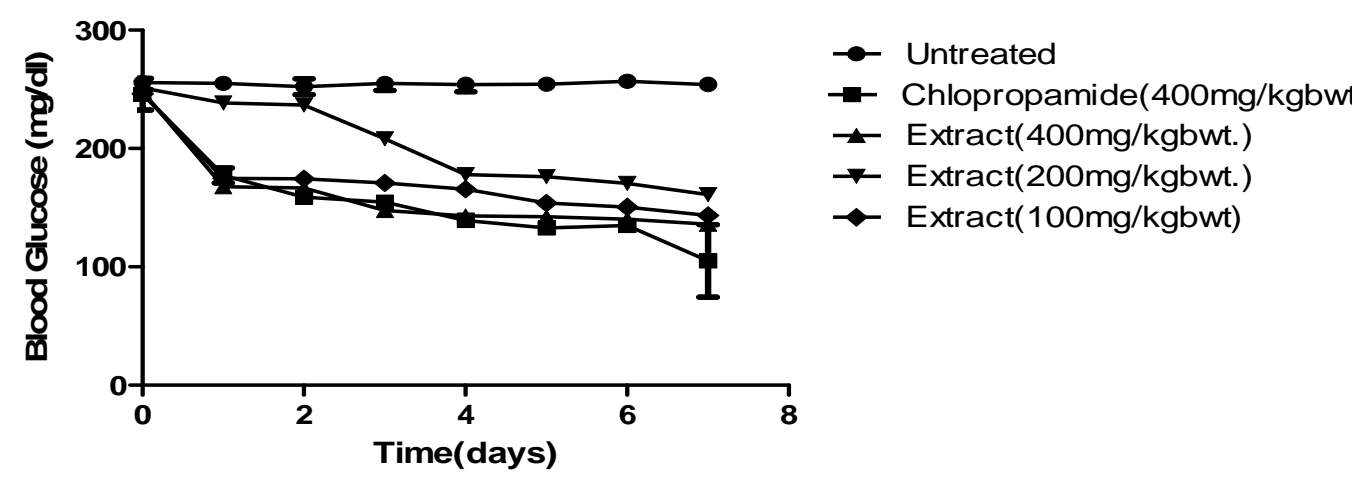

Figure 2: Effect of aqueous extract of Tapinathus sesselifolius on blood glucose levels of alloxan-induced diabetic rabbits.

Table 1: Effect of the methanol extract of Tapinathus sesselifolius on glucose absorption across the gastrointestinal smooth muscle of the rabbit intestine.

\begin{tabular}{lccccc}
\hline Treatment & \multicolumn{5}{c}{ Time (min) } \\
\cline { 2 - 6 } & $\mathbf{0}$ & $\mathbf{3 0}$ & $\mathbf{6 0}$ & $\mathbf{9 0}$ & $\mathbf{1 2 0}$ \\
\hline Control & $184.4 \pm 5.9$ & $193.7 \pm 6.2$ & $198.7 \pm 5.1$ & $179.6 \pm 8.4$ & $180.2 \pm 6.3$ \\
Ext $25 \mathrm{mg} / \mathrm{ml}$ & $165.2 \pm 6.5$ & $171.1 \pm 6.8^{*}$ & $167.4 \pm 3.5^{*}$ & $160.4 \pm 2.8^{*}$ & $159.1 \pm 4.8^{*}$ \\
Ext $50 \mathrm{mg} / \mathrm{ml}$ & $143.4 \pm 2.3$ & $158.4 \pm 4.8^{*}$ & $145.1 \pm 2.4^{*}$ & $138.7 \pm 4.8^{*}$ & $124.3 \pm 3.0^{*}$ \\
Ext $100 \mathrm{mg} / \mathrm{ml}$ & $150.3 \pm 3.4$ & $135.1 \pm 3.8^{*}$ & $127.5 \pm 2.4^{*}$ & $121.1 \pm 4.5^{*}$ & $113.5 \pm 5.7^{*}$ \\
\hline
\end{tabular}

Data are presented as mean \pm SEM. Asterisks denote statistical difference between control and treated groups. Significance difference at $\mathrm{p}<0.05$ (ANOVA followed by Dunnet's test). Ext: extract.

\section{DISCUSSION}

The result of the study revealed that the aqueous extract of $T$. sesselifolius has hypoglycemic activity in laboratory animals, by transiently decreasing the blood glucose level in normoglycemic rabbits. This decrease is a normal physiologic pattern in rodents (Tiezt, 1970) and was shown to be due to hypoglycaemic effects of plant extracts (Akah and Okafor, 1992).

The extract caused a fall in blood glucose level in alloxan treated animals. Alloxan is a widely used model for induction of experimental diabetes (Ojewole, 2004, 2005). The extract's effect was similar to that of chlorpropamide which suggests that the extract might be acting either by stimulating the $\beta$ cell to release insulin or enhance glucose utilization (Fargan et al., 1987). On daily administration, the extract caused a significant decrease in blood glucose level compared to control and this was maintained for 7 days, suggesting that the extract might be protecting the pancreas from further damage by alloxan and possibly stimulating the residual $\beta$ cells to release insulin (Obatomi et al., 1994). The aqueous extracts of the African mistletoe (Loranthus micranthus Linn of same Loranthaceae family had no adverse biochemical changes in wistar rats (Edem and Usoh, 2009) this also support the safety in acute toxicity testing.

On glucose absorption across the intestine, the extract of $T$. sesselifolius caused a concentration dependent decrease in glucose absorption. This finding indicates that the extract could decrease glucose absorption across muscle (Okachi et al., 1997), further adding to its therapeutic benefit. $T$. sesselifolius contains active component with 
hypoglycaemic activity, thus providing scientific evidence to supporting its traditional use. This activity might be attributed to flavonoids traced in the extract. Flavonoids and terpenoids have been reported to exhibit hypoglycemic activity in diabetic model by stimulation of insulin secretion and or insulin like action (Vessal et al., 2003; Shahaboddin et al., 2011) and probably due to antioxidant activity (Masibo and $\mathrm{He}, 2008$; Shahaboddin et al., 2011). Antioxidants are important in diabetes, because low levels of plasma antioxidants are important risk factor for development of diabetic complications (Luo et al., 2004). The antioxidant action of medicinal plants associated with antihyperglycemic properties may be important therapeutic properties that prevents the generation of oxidative stress that is implicated in aetiology of diabetic complications (Yaping Zhao et al., 2007).

\section{Conclusion}

The present study showed that the aqueous leaf extract of Tapinanthus sesselifolius possessed hypoglycemic properties in alloxan diabetic rabbits only, which suggest the presence of biologically active components which may be worth further investigation and characterization Further studies is going on to isolates and characterized bioactive components of the crude extract of this plant.

\section{ACKNOWLEDGEMENTS}

This work is supported by grant from the National Institute for Pharmaceutical Research and Development, Abuja, Nigeria. The authors appreciate the technical assistance of David Akumka, Hauwa Abdullahi and Sunday Dzarma. Thanks to Prof. Z. O. Gbile and Dr. John Harris Kew Gardens Edinburgh for authentication.

\section{REFERENCES}

Afolayon JA, Toafik OS. 2010. In vivo studies of Diabetic plants use in S. Africa herbal medicine. J. Clin. Biochem. Nutr., 47(2): 78-106.
Akah PA, Okafor CL. 1992. Blood sugar lowering effect of Vernonia amygdalina Del. in an experimental rabbit model. Phytother., 6: 171-173.

Alarcon-Aguila FJ, Jimenez-Estrada M, Reyes-Chilpa M, Roman-Ramos R. 2000. Hypoglycemic effect of extracts and fractions from Psacalium depompo in healthy and alloxan-diabetic mice. $J$. Ethnopharmacol., 72: 21-27.

Chattopadhyay S, Ramanatha M, Das J, Bhattacharya SK. 1997. Animal models in experimental diabetes mellitus. Indian J. Exp. Biol., 35: 1141-1145.

Edem DO, Usoh IF. 2009. Biochemical changes in wistar rats on oral doses of mistletoe (Loranthus micranthus). Amer. J. Pharmacol. Toxi., 4(3): 94-97.

Evans WC. 2002. Trease and Evans Pharmacognosy $\left(15^{\text {th }}\right.$ edn). Reed Elsevier India (Pvt) Ltd: New Delhi; 41-44; 411413.

Fargan IB, Al-Ami M, Guiger SY. 1987. Lowering of blood glucose in diabetic rabbits by Artemisia extract. $J$. Therapeutics. Fac. Mol. Biol., 92: 137141.

Fernandeze T, Marcelo L, Wagner, Beatriz G, Varela, Rafeat A, Ricso Silvia E, Hajos, Alberto A, Gurni, Elida A. 1998. Study of Argentine mistletoe, the hemiparasite Ligania cuneifolia (R. et p.) Tiegh (Lorantheceae). J. Ethnopharmacol., 62: 25-34.

Harborne JB. 1998. Phytochemical Methods: A Guide to Modern Techniques of Analysis ( $3^{\text {rd }}$ edn). Chapman and Hall: London.

Griggs P. 1991. Mistletoe, myth, magic and medicine. The Biochemist, 13: 3-4.

Hutchinson J, Dalziel JM. 1972. Flora of West Tropical Africa (Vol. 1, Part 2). The Crown Agent for the Colonies: London, UK; 464-467.

Kafaru E. 1994. Immense help from nature's workshop. Elikaf Health Services Ltd., 11. 
Lorke D. 1983. A new approach to acute toxicity testing. Archives Toxicol., 54: 275-287.

Luo Q, Cai Y, Yan J, Sun M, Corke H. 2004. Hyperglycemic and hypolipidemic effects and antioxidant activity of fruit extract from Lycium barbanum. Life Scien., 76: 137-149.

Masibo M, He Q. 2008. Major Mango polyphenols and their potential significance to human health. Compr. Rev. Food Scie. Food Safety, 7: 309-319.

Obatomi DK, Bikomo EO, Temple VJ. 1994. Anti-diabetic properties of African mistletoe in streptozotocin-induced diabetic rabbits. J. Ethnopharmacol., 43: 13-17.

Ojewole JA. 2004. Evaluation of the analgesic, anti-inflammatory and antidiabetic properties of Sclerocaya birrea (A. Rich) Hochst. Stem aqueous extract in mice and rats. Phytother. Res., 18: 601-608.

Ojewole JA. 2005. Hypoglycemic and Hypotensive effects of Psidium guajava Linn (Myrtaceae) leaf aqueous extract. Methods and Findings Exper. Clinical Pharmacol., 27(10): 689-695.

Okachi VI, Gekale AB, Obolo O, Arukwe U. 1997. Effect of Mangifera indica (Mango) leaf and bark water extracts on blood glucose level in rabbits. Nig. Qt. J. Hosp. Med., 7: 154-157.

Perfumi U, Arnold N, Tacconi R. 1991. Hypoglycemic activity of Salvia fruiticosa mill from Cyprus. $J$. Ethnopharmacol., 43: 135-140.

Shahaboddin ME, Pouramir M, Moghadamnia AA, Lakzaei M, Mirhashemi SM, Motallebi M. 2011. Antihyperglycemic and antioxidant activity of Viscum album extract. African J. Pharm. Pharmacol. 5(3): 432-436.

Tiezt NW. 1990. Carbohydrates in Fundamentals of Clinical Chemistry $\left(1^{\text {st }}\right.$ eds). W.B. Sanders Co: Philadelphia; $145-176$.
Tarfa FD, Amos S, Temple VJ, Binda L, Obodozie O, Wambebe C, Gamaniel K. 2002. Effect of the aqueous extract of African mistletoe (Tapinanthus sesselifolius P. Beauv.) Van Tiegh leaf on gastrointestinal muscle activity. Indian $J$. Exp. Biol., 40: 571-574.

Trinder P. 1969. Determination of glucose in blood using glucose oxidase with alternative oxygen acceptor. Annal. Clin. Biochem., 6: 24-27.

Vessal M, Hemmati M, Vasei M. 2003. Antidiabetic Effects of Quercetin in alloxan induced diabetic rats. Comparative Biochemistry and Physiology Part c, 135: 357-364.

Vongtau HO, Abbah J, Mosugu O, Chindo BA, Ngazal IE, Salawu AO, Kwanashie HO, Gamaniel KS. 2004. Antinociceptive profile of the methanolic extract of Neorautanania mitis root in rats and mice. J. Ethnopharmacol., 92: 317-324.

Warren-Davis. 1988. The myth of mistletoe. The Herbal Review, 13: 5-7.

WHO. 1980. Expert committee on Diabetes mellitus. Second Report. Technical Report Series 646. WHO, Geneva.

WHO. 1979. Resolution - Traditional medicine programme. WHO document, EB 6b, R4.

Wild S, Roglic G, Green A, Sicree R, King H. 2004. Global prevalence of diabetes estimates for the year 2000 and projection for 2030. Diabetes Care, 27: 1047-1053.

Ya Yaping Zhao, Young O,Sa-soon K,YoungSuk J, Jean-Chae L. 2007. Antioxidant and antihyperglycemic of polysaccharides isolated from $D$. chrysotoxum Lindl. Biochem. Molecular Biol., 40(5): 670-677. 